\title{
PARADIGMA ANALISIS WACANA DALAM MEMAHAMI TEKS DAN \\ KONTEKS UNTUK MENINGKATKAN KEMAMPUAN MEMBACA PEMAHAMAN
}

\author{
Ni Kadek Juliantari \\ STKIP Agama Hindu Amlapura \\ Email: kadekjuliantari755@yahoo.co.id
}

\begin{abstract}
Understanding the contents of the reading is achieved when appropriate paradigm of discourse analysis is used. Therefore, the mastery of the discourse analysis paradigm is very important to be mastered by the reader in order to understand the text and context of the discourse. Basically, there are three paradigms in discourse analysis, namely positivism-empirical (commonly called positivism), constructivism, and critical paradigm. Description about the discourse analysis paradigm is expected to be useful for students and teachers / lecturers who conduct study discourse analysis so that it can facilitate them in conducting discourse analysis by departing from one of these paradigms. Based on the view of the formalist (positivism-empirical paradigm), it is understandable that examining a discourse in principle is to examine the potential relationship between one sentence and another in relation to the syntax and semantics. From the functionalist's point of view (constructivism paradigm), discourse analysis is attempted as an analysis to uncover the meaning and meaning behind the discourse. Discourse analysis is an effort to reveal the hidden intent of the subject which expresses a statement by placing itself in the speaker's position with an interpretation that follows the structure of the speaker's meaning. Meanwhile, according to the critical paradigm, discourse is not understood solely as a study of language, although in the end, discourse analysis does use the language in the text to be analyzed. However, the language analyzed according to the paradigm of dialectical analysis is somewhat different from the study of language in the traditional linguistic sense. The language analyzed is not merely a description of the language aspect, but also relates it to the context.
\end{abstract}

\section{Keywords: paradigm, discourse analysis, text and context, reading}

\section{PENDAHULUAN}

Pada mulanya kata wacana dalam bahasa Indonesia digunakan untuk mengacu pada bahan bacaan, percakapan, dan tuturan. Dalam buku-buku pelajaran bahasa Indonesia, pengertian itu masih banyak dijumpai, khususnya pada bagian pelajaran membaca.Pada buku-buku itu, kata wacana digunakan sebagai kata biasa.Akan tetapi, pada pembahasan ini, wacana digunakan sebagai istilah yang merupakan padanan dari istilah discourse (dalam bahasa Inggris). 
Istilah wacana mempunyai acuan yang lebih luas dari sekadar bacaan. Akhir-akhir ini, para ahli yang berwewenang telah menyepakati bahwa wacana itu merupakan satuan bahasa yang paling besar yang digunakan dalam komunikasi (pandangan fungsional). Hal itu sejalan dengan pendapat Samsuri (1988:1) yang mengatakan bahwa "Wacana ialah rekaman kebahasaan yang utuh tentang peristiwa komunikasi”. Satuan bahasa di bawahnya secara berturut-turut adalah kalimat, frasa, kata, dan bunyi. Secara berurutan, rangkaian bunyi membentuk kata, rangkaian kata membentuk frasa, rangkaian frasa membentuk kalimat. Akhirnya, rangkaian kalimat membentuk wacana (pandangan formal).Selain itu, menurut Papirus Biru (2006), "Wacana menunjuk terutama dalam hubungan konteks sosial dari pemakaian bahasa" (pandangan dialektika).

Wacana-wacana yang ada tersebut perlu diinterpretasikan maksudnya oleh pembaca (dalam wacana tulis) atau pendengar (dalam wacana lisan). Untuk menginterpretasikan maksud-maksud di balik wacana tersebut, muncullah kajian analisis wacana. Menurut Yuris (2008), analisis wacana merupakan suatu upaya pengungkapan maksud tersembunyi dari subjek (penulis) yang membuat wacana tersebut.

Agar seseorang mudah melakukan analisis wacana, mereka harus mempunyai paradigma atau pandangan mengenai analisis wacana tersebut. Pemahaman mengenai paradigma adalah hal yang sangat fundamental. Paradigma juga memegang peranan penting bagaimana nantinya seseorang memandang sebuah wacana tersebut. Dengan demikian, analisis terhadap wacana tersebut menjadi lebih jelas.

"Paradigma mengandung pandangan tentang dunia, cara pandang untuk menyederhanakan kompleksitas dunia nyata" (Yuris, 2008). Paradigma memberi gambaran kepada kita mengenai apa yang penting, apa yang dianggap mungkin dan sah untuk dilakukan, dan apa yang dapat diterima akal sehat. Oleh karena itu, pemahaman mengenai paradigma analisis wacana penting dimiliki oleh setiap orang sebelum melakukan analisis wacana terutama dalam memahami teks dan konteks wacana tersebut.

Pada dasarnya, ada tiga paradigma dalam analisis wacana, yaitu positivisme-empiris (lazim juga disebut positivisme), konstruktivisme, dan 
paradigma kritis. Untuk lebih memahami masing-masing paradigma tersebut, timbul ketertarikan untuk menyusun artikel ilmiah tentang paradigma analisis wacana dalam memahami teks dan konteks.Paparan mengenai paradigma analisis wacana diharapkan dapat bermanfaat bagi siswa/mahasiswa dan guru/dosen yang melakukan studi analisis wacana sehingga dapat memudahkan mereka dalam melakukan analisis wacana dengan berangkat dari salah satu paradigma tersebut.

\section{PEMBAHASAN}

\section{Paradigma Analisis Wacana}

Pendapat Hikam (dalam Eriyanto, 2006:4) yang dikutip oleh Ciptaningsih (2008) menyatakan bahwa setidaknya ada tiga pandangan yang berkaitan dengan analisis wacana, yakni pandangan yang diwakili oleh kaum positivisme-empiris, pandangan konstruktivisme, dan pandangan kritis.

\section{a. Paradigma Analisis Wacana Formal}

Bagi kaum positivisme-empiris, bahasa dilihat sebagai jembatan yang ada antara manusia dengan hal-hal yang ada di luar diri manusia. Pengalaman manusia dianggap dapat secara langsung diekspresikan melalui penggunaan bahasa tanpa ada hambatan yang dinyatakan secara logis, benar secara sintaksis, dan memiliki hubungan dengan pengalaman empiris. Dalam kaitannya dengan analisis wacana, konsekuensi logis dari pemahaman ini adalah orang tidak perlu mengetahui makna-makna subjektif atau nilai-nilai yang mendasari sebuah pernyataan sebab yang penting adalah kebenaran pernyataan tersebut. Dengan kata lain, menurut pandangan ini, analisis wacana dilakukan untuk mengetahui kebenaran pernyataan tersebut,baik benar secara semantik maupun sintaksis. Oleh karena itu, analisis wacana dimaksudkan untuk menggambarkan tata aturan kalimat, bahasa, dan pengertian bersama.

Tampaknya, pandangan kaum positivisme-empiris tersebut sejalan dengan paradigma analisis wacana bagi kaum formalis yang menghasilkan paradigma analisis wacana formal. Menurut kaum formalis, wacana dipandang sebagai satuan bahasa di atas kalimat. Dengan cara pandang tersebut, wacana dipahami sebagai organisasi bahasa yang terbentuk dari unsur-unsur yang secara hierarkis 
lebih kecil tatarannya, yakni berupa klausa dan kalimat. Dengan demikian, mengkaji suatu wacana pada prinsipnya adalah mengkaji hubungan potensial antara kalimat yang satu dengan kalimat yang lain dalam kaitannya dengan sintaksis dan semantik.

Demikian pula halnya dengan Fairclough. Fairclough juga membagi analisis wacana berdasarkan tiga pandangan. Akan tetapi, penyebutannya saja yang berbeda dengan pendapat Hikam di atas. Menurut Fairclough (dalam Wahyudi,2008), teks dianalisis secara linguis dengan memperhatikan kosakata, semantik, dan tata kalimat. Selain itu, Fairclough juga memasukkan unsur kohesi dan koherensi dalam melakukan analisis wacana berdasarkan pandangan formal ini.

\section{b. Paradigma Analisis Wacana Fungsional}

Wacana dipandang sebagai bahasa dalam penggunaan. Dengan cara pandang tersebut, wacana dipahami sebagai peristiwa komunikasi, yakni perwujudan dari individu yang sedang berkomunikasi. Jadi, bahasa yang digunakan oleh pembicara dipandang sebagai wujud dari tindakan pembicaranya.

Pandangan kedua yang disampaikan oleh Hikam adalah konstruktivisme. Dalam pandangan ini, bahasa tidak lagi dipandang sebagai alat untuk memahami realitas objektif belaka dan yang dipisahkan oleh subjek sebagai penyampai pernyataan. Konstruktivisme justru menganggap subjek sebagai faktor sentral dalam kegiatan wacana dan hubungan-hubungan sosial lainnya. Oleh karena itu, analisis wacana diupayakan sebagai suatu analisis untuk membongkar maksud dan makna tertentu di balik wacana tersebut. Analisis wacana adalah suatu upaya pengungkapan maksud tersembunyi dari sang subjek yang mengemukakan suatu pernyataan dengan cara menempatkan diri pada posisi pembicara dengan penafsiran yang mengikuti struktur makna sang pembicara.

Di samping itu, Fairclough mengemukakan pandangannya yang kedua terkait dengan paradigma analisis wacana fungsional. Analisis wacana berdasarkan pandangan fungsional tersebut oleh Fairclough disebut discourse practice. Discourse practice merupakan suatu dimensi analisis wacana yang memiliki hubungan dengan proses produksi dan komunikasi karena bagi 
Fairclough analisis linguistik teks tidak bisa dilepaskan dari analisis praktik kewacanaan (Jorgensen dan Philips dalam Wahyudi, 2008). Analisis seperti ini dipusatkan pada ketergantungan pengarang teks terhadap wacana-wacana yang ada untuk mencipta suatu teks dan bagaimana penerima teks menerapkan wacana yang ada dalam komunikasi dan interpretasi teks.

\section{c. Paradigma Analisis Wacana Dialektika}

Wacana dipandang sebagai ujaran, yakni dipahami sebagai suatu kumpulan unit struktur bahasa yang tidak lepas dari konteks. Dengan cara pandang tersebut keberadaan kalimat dalam suatu wacana tidak sekadar dipandang sebagai sistem (langue), tetapi juga dipandang sebagai parole. Meskipun ujaran dalam suatu wacana disusun berdasarkan gramatika (sistem bahasa), makna ujaran timbul karena lawan bicara juga memperhatikan konteks penggunaan bahasanya. Dengan demikian, selain kaidah tata bahasa, konteks penggunaan bahasa juga harus diperhatikan pada saat menyusun suatu wacana.

Hal itu dipertegas oleh pandangan ketiga dari Hikam,yakni pandangan kritis. Pandangan ini ingin mengoreksi pandangan konstruktivisme yang kurang sensitif pada proses produksi dan reproduksi makna yang terjadi secara historis maupun institusional. Pandangan konstruktivisme dikatakan belum menganalisis faktor-faktor hubungan kekuasaan yang inheren dalam setiap wacana, yang pada gilirannya berperan dalam membentuk jenis-jenis subjek tertentu beserta perilakuperilakunya. Pemikiran inilah yang nantinya melahirkan paradigma kritis.

Analisis wacana dalam pandangan ini menekankan konstelasi kekuatan yang terjadi pada proses produksi dan reproduksi makna. Dalam hal ini, bahasa tidak dipahami sebagai media netral yang terletak di luar diri si pembicara. Bahasa dalam pandangan kritis dipahami sebagai representasi yang berperan membentuk tema, wacana, ataupun strategi-strategi tertentu. Karena memakai perspektif kritis, analisis wacana ketiga ini juga disebut sebagai Analisis Wacana Kritis (yang selanjutnya disingkat AWK).AWK secara lebih mendalam akan dibahas pada bagian khusus.

Selanjutnya, pandangan ketiga dari Fairclough, yakni mengenai konteks sosiocultiral practiceyang tampaknya selajan dengan pandangan/paradigma 
dialektika tersebut. Dalam konteks sosiocultural practice harus dipahami bahwa teks yang muncul sangat dipengaruhi oleh bagaimana konteks sosial tersebut tecermin dalam wacana yang terbentuk.Dalam analisis wacana sesuai dengan paradigma dialektika,konteks ini penting karena tujuan AWK(yang disebut Fairclough sebagaisosiocultural practice)adalah untuk mengeksplorasi antara penggunaan bahasa dan praktik sosial, serta fokusnya adalah untuk memperlihatkan peran kewacanaan dalam melestarikan tatanan sosial dan perubahan sosial.

Dalam pandangan Fairclough, setiap peristiwa komunikatif dipandang sebagai praktik sosial yang berfungsi untuk mendukung atau menentang tatanan wacana (Jorgensen \& Phillips, dalam Wahyudi, 2008). Sosiocultural practicebisa dipandang sebagaipenggambaran mengenai kekuatan-kekuatan atau kekuasaankekuasaan yang ada dalam masyarakat.Pemaknaan dan penyebaran ideologi kepada masyarakat, ditentukan olehsosiocultural practiceatau wacana yang berkaitan dengan konteks sosial dan budaya (Eryanto, dalam Wahyudi, 2008). Artinya ketika ada perubahan wacana, disitu terjadi perubahan sosiokultural, begitu pula sebaliknya.

Dalam menganalisis wacana menurut pandangan ini, wacana tidak dipahami semata-mata sebagai studi bahasa, walaupunpada akhirnya, analisis wacana memang menggunakan bahasa dalam teks untuk dianalisis. Akan tetapi, bahasa yang dianalisis menurut paradigma analisis dialektika ini agak berbeda dengan studi bahasa dalam pengertian linguistik tradisional. Bahasa dianalisis bukan sekadar menggambarkan dari aspek kebahasaan, tetapi juga menghubungkannya dengan konteksnya. Penggambaran wacana sebagai praktik sosial menyebabkan sebuah hubungan dialektis di antara peristiwa diskursif tertentu dengan situasi, intuisi, dan struktur sosial yang membentuknya. Praktik wacana kemungkinan menampilkan efek ideologi, misalnya dapat memproduksi hubungan kekuasaan yang tidak imbang antara kelas sosial, laki-laki dan wanita, kelompok mayoritas dan minoritas. 


\section{Analisis Wacana Kritis}

Analisis wacana telah mengalami perkembangan yang luar biasa cepatnya. Suatu cabang ilmu bahasa yang pada tahun 70-an belum banyak dikenal, kini telah berkembang begitu cepat dan berbagai metodenya telah digunakan oleh tidak hanya para linguis, tetapi juga para ahli ilmu sosial dan para ahli lainnya. Para ahli ilmu sosial, misalnya, kini mulai melirik kegunaan analisis wacana yang menyebut cabang ilmu ini sebagai Critical Discourse Analysis atau Analisis Wacana Kritis (AWK).

Bagi Santoso (2009), AWK adalah analisis bahasa dalam penggunaannya dengan menggunakanparadigma bahasa kritis. AWK sering dipandang sebagai oposisi analisis wacana deskriptif yang memandang wacana sebagai fenomena teks bahasa semata-mata, padahal tidak demikian. Dalam AWK, wacana tidak dipahami semata-mata sebagai kajian bahasa.AWK memang menggunakan bahasa dalam teks untuk dianalisis. Hasilnya bukan untuk memperoleh gambaran dari aspek kebahasaan, melainkan menghubungkannya dengan konteks. Hal itu berarti bahwa bahasa itu dipergunakan untuk tujuan dan praktik tertentu, termasuk di dalamnya praktik kekuasaan.

\section{a. Piranti Analisis Wacana Kritis}

Seperti halnya analisis wacana pada umumnya, AWK juga menggunakan piranti analisis yang sama dengan analisis wacana (biasa) untuk menginterpretasikan maksud pembuat wacana tersebut. Piranti AWK di antaranya dipaparkan berikut ini.

\section{1) 'Common Sense' dan 'Idiology'}

Idiologi yang digunakan dalam AWK sedikit berbeda dari pengertian yang biasa digunakan dalam banyak hal, terutama di bidang politik. Seperti yang dikemukakan oleh Fairclough (dalam Purwo, Ed., 2000), idiologi diinterpretasikan sebagai suatu kebijakan masyarakat yang sebagian atau seluruhnya berasal dari teori sosial secara sadar. Dalam AWK, idiologi tidak hanya terbatas pada pengertian politis, tetapi mempunyai pengertian yang lebih luas lagi. Sejak dahulu, misalnya, rakyat Indonesia telah mengenal hidup bergotong royong. Mereka mengenalnya sebelum secara resmi gotong-royong itu 
diangkat menjadi salah satu sila dalam Pancasila. Pengertian yang semacam itulah yang disebut dengan ideologi AWK oleh Fairclough (dalam Purwo, Ed., 2000).

Bagi rakyat banyak, hidup bergotong-royong merupakan cara hidup yang sangat menonjol. Setelah bangsa Indonesia menetapkan Pancasila sebagai ideologi bangsa dan negara, pengertian Pancasila bagi masyarakat banyak merupakan suatu "common sense" yang bersumber pada ideologi bangsa. Fairclough (dalam Purwo, Ed., 2000) menyebutnya sebagai “ideological common sense".

\section{2) Asumsi yang Implisit, Koherensi, dan Inferensi}

Seperti analisis wacana pada umumnya, AWK juga menggunakan piranti seperti asumsi yang implisit, koherensi, dan inferensi untuk mendapatkan interpretasi yang baik dan dekat sekali dengan kenyataan atau dengan makna yang disampaikan oleh penutur atau penulis.Untuk lebih memahami piranti ini, berikut dipaparkan sebuah contoh.

\section{“ Polwan" Sikat Emas 86,8 Gram}

Dwi Setyowati (27), yang memang berpostur mirip polisi wanita itu dituduh mencuri seluruh perhiasan emas milik M. Nasir seberat 86,8 gram. "Saya benarbenar tidak menyangka bahwa dia itu polwan gadungan. Selain penampilannya meyakinkan, dia juga istri teman baik saya", cerita Nasir di Polsekta Krembangan. (dikutip dari Kartomihardjo, 2000, dalam artikelnya "Kekuasaan dalam Bahasa")

Baru sampai pada bagian itu saja, pembaca sudah dapat membayangkan seperti apa wujud polisi gadungan itu. Diceritakan oleh Nasir bahwa badan polwan gadungan itu tampak seperti polwan sungguhan, misalnya berbadan tinggi, tegap, tegas, dan kekar. Gambaran seperi itu, diperoleh dari tulisan wartawan yang menyatakan "berpostur mirip polisi wanita", sedangkan keterangan lainnya diperoleh berdasarkan pengetahuan pembaca tentang polwan yang biasa dijumpai dalam kehidupan sehari-hari.

Selanjutnya, Nasir menceritakannya kepada polisi,

"Lutfi Masailla, teman sekerja saya mengatakan bahwa dia baru saja diusir dari tempat kosnya di jalan Jakarta; dia mencari tumpangan semtara." Nasir tidak bisa menolaknya karena Lutfi teman sekantornya. Hari itu Nasir dikenalkan dengan Dwi yang diakui Lutfi sebagai istrinya. Dwi mengaku kepada Nasir bahwa ia anggota polisi berpangkat kapten yang akan bertugas di Surabaya. Dua hari berselang Nasir dikejutkan oleh hilangnya Lutfi dan Dwi dari rumahnya, serta raibnya emas seberat 
86,8 gram dari lemari Nasir.(dikutip dari Kartomihardjo, 2000, dalam artikelnya

"Kekuasaan dalam Bahasa")

Sampai pada bagian tersebut, pembaca sudah menginterpretasikan bahwa Dwi yang diakui sebagai istri Lutfi mungkin bukan istri yang sesungguhnya dan Lutfi bukanlah teman karib Nasir sebab Nasir belum kenal Dwi (yang diperkenalkan sebagai istri Lutfi). Pengetahuan pembaca tentang "dunia" mengatakan bahwa teman karib diketahui asal-usulnya dan juga anggota keluarganya terdekat, terutama istri teman karib itu. Dengan pengetahuan itu, pembaca dapat menginterpretasikan bahwa Lutfi bukan teman karib Nasir sehingga Nasir telah melakukan kesalahan besar karena mengizinkan Lutfi dan polwan gadungan itu menginap di rumahnya. Pembaca juga dapat menginterpretasikan bahwa emas tersebut tentu telah dicuri oleh Lutfi dan Dwi.

Pemahaman pembaca tentang polwan gadungan, tentang pencurian, tentang kebohongan yang dilakukan Lutfi, semuanya itu telah dapat dipahami dan telah menjadi suatu koheren setelah pembaca menghubung-hubungkan kejadiankejadian yang ditulis wartawan dengan menggunakan inferensi-inferensi atau simpulan-simpulan.

\section{3) Interpretasi Pembaca dan Interpretasi Penulis}

Seorang pembaca tentu ingin mengetahui atau menginterpretasikan sesuatu atau maksud yang ditulis oleh penulis. Suatu wacana melibatkan kondisi sosial yang spesifik. Apabila bahasa dilihat sebagai wacana dan sebagai praktik sosial, seseorang perlu melihatnya sebagai analisis tentang hubungan antara teks, proses, dan kondisi sosial.

Ada tiga dimensi atau tahap AWK yang dipaparkan oleh Kartomihardjo (dalam Purwo, Ed., 2000:116). Dimensi AWK tersebut di antaranya adalah deskripsi, interpretasi, dan eksplanasi. Deskripsi adalah hal-hal yang menyangkut properti formal dari suatu teks; interpretasi adalah hal-hal yang menyangkut hubungan antara teks dan interaksi dengan melihat teks sebagai hasil dari suatu proses produksidan sebagai sumber dalam proses interpretasi; sedangkan eksplanasi adalah hal-hal yang menyangkut hubungan antarainteraksi dan konteks sosial. Perlu diingat bahwa setiap dimensi itu, analisis terhadap wacana akan 
berubah. Pada tahap deskripsi yang dilakukan adalah melihat bagaimana teks disusun menurut kosakatanya, tata bahasanya, dan struktur tekstualnya. Pada tahap interpretasi, teks dianalisis sebagai suatu hasil dari proses produksi. Sementara itu, pada tahap eksplanasi, teks dianalisis sebagai suatu interaksi yang dikaitkan dengan konteks sosialnya.

\section{Karakteristik Analisis Wacana Kritis}

Rosidi dan Jufri (dalam Arifin, Ed. 2004:11) memaparkan beberapa karakteristik AWK. Karakteristik AWK meliputi prinsip tindakan, konteks, hegemoni (ideologi dan kekuasaan), dan sejarah (historis). Berikut pemaparan masing-masing prinsip tersebut dengan penambahan seperlunya dari penulis.

Prinsip pertama adalah prinsip tindakan. Prinsip tindakan pada hakikatnya memandang suatu wacana sebagai sesuatu yang bertujuan, baik bertujuan memengaruhi, berdebat, membujuk, menanggapi, maupun menyarankan dan tentunya masih banyak tujuan-tujuan lain yang ingin disampaikan penulis kepada pembaca melalui wacana yang dibuatnya. Dengan demikian, berdasarkan prinsip yang pertama ini, wacana dapat dipahami sebagai suatu interaksi antara penulis dan pembaca atau penutur dan petutur yang memiliki tujuan tertentu.

Selain itu, menurut Fairclough dan Wodak (dalam Yuris, 2008), wacana dapat dipahami sebagai tindakan (actions), yaitu mengasosiasikan wacana sebagai bentuk interaksi. Seseorang berbicara dan menulis menggunakan bahasa untuk berinteraksi dan berhubungan dengan orang lain. Selain itu, wacana dipahami sebagai sesuatu yang diekspresikan secara sadar dan terkontrol, bukan sesuatu di luar kendali atau diekspresikan secara tidak sadar.

Prinsip kedua adalah prinsip konteks. Konteks yang meliputi latar, situasi, peristiwa, dan kondisi sangat penting dikaji dalam AWK. Menurut Suparno (dalam Arifin, 2004:11), kajian kewacanaan dalam konteks itu meliputi topik, partisipan (penulis/penutur dan pembaca/petutur), waktu dan tempat, saluran komunikasi, kode, situasi komunikasi, budaya atau adat istiadat berkomunikasi.

Fairclough dan Wodak (dalam Yuris, 2008) berpendapat bahwa wacana dipandang, diproduksi, dimengerti dan dianalisis dalam konteks tertentu. Kemudian Guy Cook (dalam Papirus Biru, 2006) menjelaskan bahwa analisis 
wacana memeriksa konteks dari komunikasi: siapa yang berkomunikasi dengan siapa dan mengapa; khalayaknya siapa, situasi apa, melalui medium apa, bagaimana, perbedaan tipe dan perkembangan komunikasi,serta hubungan masing-masing pihak. Tiga hal sentaralnya adalah teks, konteks, dan wacana. Teksmerupakan semua bentuk bahasa, bukan hanya kata-kata yang tercetak pada kertas, tetapi semua jenis ekspresi komunikasi,ucapan, musik gambar, efek suara, citra, dan sebagainya. Konteks merupakan memasukan semua jenis situasi dan hal yang berada diluar teks dan memengaruhi pemakaian bahasa, seperti partisipannya, situsai saat teks itu diproduksi, dan fungsi yang dimaksud. Wacana dimaknai sebagai suatu konteks dan teks secara bersama. Fokus penekanannya dalam hal iniadalah analisis wacana menggambarkan teks dan konteks secara bersama-sama dalam proses komunikasi.

Prinsip ketiga adalah hegemoni (ideologi dan kekuasaan). Pada hakikatnya sebuah wacana adalah cermin dari hegemoni atau ideologi tertentu. Hegemoni, menurut Fairclough (dalam Arifin, Ed. 2004:12), "lebih menekankan pada teori kekuasaan dengan pemahaman bahwa kekuasaan suatu komunitas yang dominan dapat menguasai komunitas yang lain.”

Dengan kata lain, AWK mempertimbangkan elemen kekuasaan. Wacana dalam bentuk teks, percakapan atau apa pun tidak di pandang sebagai sesuatu yang alamiah, wajar, dan netral, tetapi merupakan bentuk pertarungan kekuasaan. Konsep kekuasaan yang dimaksudkan adalah salah satu kunci hubungan antara wacana dan masyarakat. Sebagai contohnya adalah kekuasaan laki-laki terhadap wanita dalam wacana mengenai seksisme, kekuasaan kulit putih terhadap kulit hitam dalam wacana mengenai rasisme, kekuasaan perusahaan dalam bentuk dominasi pengusaha kelas atas terhadap bawahan, dan sebagainya.

Di samping itu, ideologi adalah salah satu konsep sentral dalam AWK karena setiap bentuk teks, percakapan, dan sebaginya adalah praktik ideologi atau pancaran ideologi tertentu. Wacana bagi ideologi adalah suatu meduim untuk menunjukkan cara kelompok dominan mempersuasi dan mengkomunikasikan kepada khalayak mengenai kekuasaan yang mereka miliki sehingga absah dan benar (Yuris, 2008). 
Sesungguhnya, pemakai bahasa tidak hanya berkedudukan sebagai pembicara, penulis, pendengar, dan pembaca, tetapi mereka juga merupakan bagian dari anggota sosial tertentu, bagian dari kelompok professional, agama, komunitas atau masyarakat tertentu. Hal ini mengimplikasikan bahwa AWK tidak membatasi analisisnya pada hal-hal yang ada di dalam teks atau struktur wacana saja, tetapi juga menghubungkan kekuasaan dengan kondisi sosial, politik, ekonomi, dan budaya tertentu.

Kekuasaan dalam hubungannya dengan wacana penting untuk melihat apa yang disebut dengan kontrol. Bentuk kontrol tersebut terhadap wacana bisa bermacam-macam. Bisa berupa kontrol atas konteks, yang secara mudah dapat dilihat dari siapakah yang boleh dan harus berbicara, dan sementara siapa pula yang hanya mendengar dan mengiyakan. Selain konteks, kontrol tersebut juga diwujudkan dalam bentuk mengontorol struktur wacana. Hal ini dapat dilihat daripenonjolan atau pemakaian kata-kata tertentu.

Prinsip keempat adalah prinsip historis. Berdasarkan prinsip historis ini, sebuah teks dianalisis dengan pertimbangan bahwa wacana tersebut ketika diproduksi ada pada konteks tertentu. Jadi, untuk menganalisis sebuah wacana perlu diperhatikan konteks saat wacana tersebut diproduksi.Historis, menempatkan wacana dalam konteks sosial tertentu dan tidak dapat dimengerti tanpa menyertakan konteks (Fairclough dan Wodak dalam Yuris, 2008).

Dengan kata lain, salah satu aspek penting untuk dapat memahami teks adalah dengan menempatkan wacana tersebut pada konteks historis tertentu. Misalnya, kita melakukan analisis wacana teks selebaran mahasiswa menentang Suharto. Pemahaman mengenai wacana teks ini hanya akan diperoleh kalau kita bisa memberikan konteks historis saat teks itu diciptakan, seperti bagaimana situasi sosial politik saat itu. Oleh karena itu, pada saat melakukan analisis perlu tinjauan untuk mengerti mengenai mengapa wacana seperti itu berkembang atau dikembangkan seperti itu, mengapa bahasa yang dipakai seperti itu, dan seterusnya.

Berdasarkan beberapa karakteristik AWK tersebut, Fairclough (dalam Papirus Biru, 2006) memandang bahasa sebagai praktik kekuasaan. Karena bahasa secara sosial dan historis dianggap sebagai bentuk tindakan, dalam 
hubungan dialektik dengan struktur sosial; dalam menganalisis wacana, Fairclough memusatkan pada bagaimana bahasa itu terbentuk dan dibentuk dari relasi sosial dan konteks sosial tertentu.

\section{PENUTUP}

Berdasarkan uraian pada bab 2 tersebut, dapat disimpulkan bahwa ada tiga paradigma yang mendasari seseorang melakukan analisis wacana, yakni paradigma formal, paradgima fungsional, dan paradigma kritis. Untuk memudahkan seseorang menganalisis suatu wacana, mereka harus berangkat dari salah satu pandangan tersebut. Dengan demikian, analisis terhadap wacana yang dilakukan menjadi semakin jelas, terutama dalam memahami teks dan kontes wacana tersebut..

Melalui kesempatan ini, disampaikan saran kepada pembaca (siswa/mahasiswa dan guru/dosen), hendaknya jangan mencampuradukkan ketiga pandangan/paradigma tersebut ketika menganalisis suatu wacana agar tidak membingungkan pembaca dan tentunya membingungkan diri sendiri saat melakukan analisis. Selain itu, disarankan juga agar pembaca melakukan kajian yang lebih mendalam mengenai paradigma analisis wacana untuk menambah khazanah ilmu pengetahuan.

\section{DAFTAR PUSTAKA}

Arifin, Ed. 2004. Analisis Wacana (Beberapa Teori Dasar dan Aplikasinya). Kumpulan Makalah (tidak diterbitkan). Program Studi Pendidikan Bahasa Indonesia, Program Pascasarjana, Universitas Negeri Malang.

Biru, Papirus. 2006. "Analisis Wacana". http://papirusbiru.blogspot.com/2006/08/analisis-wacana.html. Diakses 13 November 2009.

Ciptaningsih, Putu Widi. 2008. Analisis Berita tentang Pembangunan Pabrik Miras di Tabanan dalam Harian "Bali Post" Berdasarkan Model Theo Van Leeuwen. Skripsi (tidak diterbitkan). Jurusan PBSID, FBS, Undiksha.

Kartomihardjo, Soesono. 2000. "Kekuasaan dalam Bahasa”. Universitas Negeri Malang.

Purwo, Bambang Kaswanti, Ed. 2000. Kajian Serba Linguistik. Jakarta: PT BPK Gunung Mulia. 
Samsuri. 1988. Analisis Wacana. Malang: Proyek Peningkatan/Pengembangan Perguruan Tinggi IKIP Malang.

Santoso, Anang. 2009. "Jejak Halliday dalam Linguistik Kritis dan Analisis Wacana Kritis”. http://sastra.um.ac.id/wp-content/uploads/2009/10/JejakHalliday-dalam-Linguistik-Kritis-dan-Analisis-Wacana-Kritis-AnangSantoso.pdf. Diakses 13 November 2009.

Wahyudi, Hardian. 2009. “Analisis Wacana Sebuah Perspektif”. http://hardianwahyudi menulis.blogspot.com/2009/06/analisis-wacanasebuah-perspektif.html. Diakses 4 Oktober 2009.

Yuris, Yulianus Andre. 2008. "Studi Analisis Wacana Kritis". http://andreyuris.wordpress.com/2008/08/08/studi-analisis-wacanakritis/html. Diakses 13 November 2009. 